\title{
Cu25W Kompozit Tozunun Bilyeli Öğütme Yöntemiyle Üretimine Farklı İşlem Kontrol Katkılarının Etkisinin İncelenmesi
}

\author{
Investigation of the Effect of Different Process Control Agents on the Production of Cu25W \\ Composite Powder via Ball Milling Technique
}

\author{
Serkan BIYIK* \\ Karadeniz Teknik Üniversitesi, Abdullah Kanca Meslek Yüksekokulu, Makine ve Metal Teknolojileri Bölümü, 61530, Trabzon
}

• Geliş tarihi / Received: 25.05.2018 • Düzeltilerek geliş tarihi / Received in revised form: 02.08.2018 • Kabul tarihi / Accepted: 08.08 .2018

\begin{abstract}
$\ddot{O} z$
Bakır $(\mathrm{Cu})$ esaslı kompozitler, özellikle de tungsten $(\mathrm{W})$ veya molibden gibi refrakter metal içeren bileşimler geleneksel malzemelere göre daha geniş bir sıcaklık aralı̆̆ında üstün fiziksel ve mekanik özellikler sergilerler. Cu-esaslı refrakter metal içerikli kompozitler yüksek sertlikleri, iyi derecede 1sıl ve elektriksel iletkenlikleri ve ark-erozyonuna karşı yüksek dirençleri sebebiyle özellikle elektrik kontak malzemeleri olarak yaygın bir şekilde kullanılmaktadır. Söz konusu kompozitlerin bilyeli öğütme yöntemiyle üretimi mümkün olmakla birlikte bu yöntemde mevcut olan işlem kontrol katkısı, öğütme hızı, bilye-toz-ağırlık oranı, öğütme süresi vb. gibi birçok işlem değişkenlerinin etkilerinin ayrı ayrı incelenmesi önem arz etmektedir. Bu çalışmada; bilyeli öğütme değişkenlerinden bir tanesi olan işlem kontrol katkısının, Cu-esaslı W-takviyeli kompozit tozunun üretimine olan etkisi incelenmiştir. Bu amaçla sıvı işlem kontrol katkılarından olan etanol ve metanol; element haldeki $\mathrm{Cu}$ ve $\mathrm{W}$ tozlarından hazırlanan karışımlara ayrı ayrı katılarak iki istasyonlu gezegen tip bilyeli ögütücüde öğütme işlemleri gerçekleştirilmiştir. Etanol ve metanol katkılarının Cu25W toz boyut ve morfolojisine olan etkileri parçacık boyut analizi ve taramalı elektron mikroskopisi (SEM) kullanılarak incelenmiştir. Artan öğütme süresi ile birlikte her iki bileşimde de ortalama parçacık boyutunda azalma gözlenmiştir. Söz konusu azalma özellikle metanol katkısı içeren toz karışımında daha belirgin olduğundan dolayı Cu25W kompozit tozunun üretiminde ağırlıkça \% 2'lik oran için bir işlem kontrol katkısı olarak metanolün etanole göre daha etkili olduğu görülmüştür. Ayrıca, metanol katkısı ile 25 saatlik öğütme süresi sonunda etanol katkılı toz karışımına nazaran daha homojen bir dağılım elde edildiği görülmüştür.
\end{abstract}

Anahtar kelimeler: Bakır-esaslı kompozitler, Bilyeli öğütme, Etanol, İşlem kontrol katkısı, Metanol, Tungsten

\begin{abstract}
Copper (Cu) based composites, especially compositions containing refractory metals such as tungsten (W) or molybdenum, exhibit superior physical and mechanical properties over a wide range of temperatures compared to conventional materials. Due to their high hardness, good electrical and thermal conductivities, and excellent arcerosion resistance; Cu-based refractory metal reinforced composites are frequently used as electrical contact materials. Although, it is possible to produce aforementioned composites via ball milling technique, this method also contains several parameters that have to be investigated in detail, such as process control agent, milling speed, ball-topowder weight ratio, milling time, and so on. In this paper; the effect of process control agent, which is one of the most important parameters in ball milling technique, on production of Cu-based W-reinforced composite powder was investigated. For this purpose, two different liquid process control agents, namely ethanol and methanol were separately added to powder mixtures containing elemental $\mathrm{Cu}$ and $W$, and then ball milling experiments were performed using a two stationary planetary-type ball mill. The effects of ethanol and methanol additions on particle size and morphology of $\mathrm{Cu} 25 \mathrm{~W}$ powder mixture were investigated using laser diffraction analysis (Mastersizer) and scanning electron microscopy (SEM). It was found that average particle size values of both compositions decreased with increasing milling duration. Considering its improved particle size reduction effectiveness as a process control agent, methanol at the amount of $2 \mathrm{wt} \%$ was found to be more effective comparing to the same amount of ethanol in terms of producing Cu25W composite powder. Besides, more homogeneous dispersion of elements was achieved in powder mixture containing methanol after ball milling duration of 25 hours.
\end{abstract}

Keywords: Copper-based composites, Ball milling, Ethanol, Process control agent, Methanol, Tungsten

\footnotetext{
* Serkan BIYIK; serkanbiyik@ktu.edu.tr; Tel: (0462) 377 81 84; orcid.org/0000-0002-6083-0802
} 


\section{Giriş}

Elektrik kontakları röle veya kontaktör gibi elektromanyetik anahtarların en önemli elemanlarından biri olup elektrik devresinin belirlenen zamanlarda açılıp kapanması görevini üstlenirler. Kontaklar, üzerlerinden elektrik akımı geçtiği için hem mekanik hem de elektriksel olarak aşınmaya maruz kalırlar. Elektriksel aşınma veya ark-erozyonu özellikle iki kontak arasındaki malzeme transferinin ve kontak yüzeylerindeki bozunumların en önemli sebebidir (B1y1k vd., 2015; Li vd., 2017; Zhu vd., 2017). Elektrik kontaklarının sürekli açılıp kapanması ile veya artan çevrim sayıları ile kontak yüzeylerindeki bozunum ve malzeme kaybı da artmaktadır (Bıyık ve Aydın, 2016). Elektrik kontaklarında oluşabilecek bir arıza kentlerde enerji çöküşü, telefon sistemlerinin bozulması ve hatta bir uçağın kontrolden çıkması gibi çeşitli trajik sonuçlar doğurabilir. Bu yüzden elektrik kontakları için tercih edilecek malzemelerin yüksek 1sıl ve elektriksel iletkenlik, yüksek sertlik, oksit, sülfür ve diğer bileşiklere karşı yüksek reaksiyon direnci ve yüksek ergime sıcaklığı gibi birtakım özelliklere sahip olmaları arzu edilir (Feng vd., 2005; Pandey vd., 2008; Cosovic vd., 2012). Ancak hiçbir malzeme bütün bu özelliklere tek başına sahip olmadığından emniyet, tedarik edilebilme, ömür ve maliyet gibi değişkenler göz önüne alınarak belirlenen her uygulama için farklı özelliklere sahip malzemelerin bir araya getirilmesi zorunluluğu ortaya çıkmaktadır. Bu bağlamda elektrik endüstrisindeki çoğu kontak uygulamalarında bakır $(\mathrm{Cu})$ esaslı kompozit kontak malzemeleri tercih edilmektedir (B1y1k ve Aydın, 2015; Shi vd., 2015). Bakırın özellikle yüksek sıcaklıklardaki ark-erozyon performansını iyileştirmek ve sertliğini artırmak için tungsten (W) veya molibden gibi refrakter metaller kullanılmakta ve yeni kompozitler geliştirilmektedir (Biy1k, 2017; Dong vd., 2017; Yusefi ve Parvin, 2017). Kompozitlerin üretiminde geleneksel toz metalurjisi (TM) yöntemi kullanılırken, kompozit tozların üretiminde bilyeli öğütme yönteminden faydalanılmaktadır (B1y1k ve Aydın, 2017/1). Bilyeli öğütme yöntemi ile soğuk kaynak ve kırılma olayları arasındaki denge sağlandığında toz parçacıklarındaki boyut küçülmeleri ile birlikte daha homojen dağılımlı içyapılar elde edilebilmektedir (Bıyık ve Aydın, 2017/2). Homojenliğin sağlanamaması ve yerel bileşim farklılıkları (segregasyon) gibi durumlar kontakların performansını olumsuz etkileyeceğinden bilyeli öğütme yönteminin önemi burada ön plana çıkmaktadır. Bilyeli öğütme yönteminden alınacak verim, toz karışımına ilave edilecek işlem kontrol katkılarının türü ve miktarı ile doğrudan ilişkilidir (Suryanarayana, 2004). İşlem kontrol katkıları kat1, sıv1 veya gaz halde olabilir. Kullanılan toz karışımının içeriğine (sünek veya gevrek toz) bağlı olarak en uygun işlem kontrol katkısının ve miktarının, yapılacak ögütme deneyleri ile belirlenmesi gerekir. Katı işlem kontrol katkıları olarak stearik asit, polietilen glikol (PEG) ve çinko stearat kullanılırken sıvı halde en çok tercih edilen işlem kontrol katkıları etanol ve metanoldür. Özellikle elektrik kontak malzemelerinin üretimi gibi yüksek saflık gerektiren uygulamalarda, katı işlem kontrol katkılarının sıvı işlem kontrol katkılarına göre içyapıda safsızlık oluşturma eğilimleri daha yüksek olabileceği için sıv1 işlem kontrol katkılarına yönelim daha uygun görülmüştür. $\mathrm{Bu}$ nedenle bu çalışmada bilyeli öğütme yöntemi kullanılarak etanol ve metanol gibi iki farklı türde sıvı işlem kontrol katkısı içeren $\mathrm{Cu}-\mathrm{W}$ kompozit tozları üretilmiş ve bunların toz boyutu ve morfolojisindeki değişimler incelenerek daha homojen bir içyapı elde edilmesi ve böylece kontak performansını iyileştirici etki yaratılması amaçlanmıştır.

\section{Amaç, Gereç ve Yöntem}

$\mathrm{Bu}$ çalışmada matris fazı olarak $\mathrm{Cu}$, takviye fazı olarak ise $\mathrm{W}$ tercih edilmiştir. Bilyeli öğütme deneylerinde kullanılan başlangıç tozları sırasıyla elementel $\mathrm{Cu}$ (maksimum toz boyutu $44 \mu \mathrm{m}, \% 99$ saflikta) ve W (ortalama toz boyutu $12 \mu \mathrm{m}, \%$ 99.9 saflıkta) tozlarıdır. Başlangıç toz morfolojilerinin taramalı elektron mikroskobu (Zeiss Evo LS 10) görüntüleri Şekil 1'de gösterilmiştir. Öncelikle başlangıç tozları 75:25 ağırlık oranlarında karıştırılarak aynı içeriğe sahip iki karışım hazırlanmıştır. Hazırlanan karışımlara \% 2'lik ağırlık oranında işlem kontrol katkıları (etanol ve metanol) ilave edilmiştir. Böylece iki farklı sıvı işlem kontrol katkısı içeren iki ayrı karışım elde edilmiştir. Hazırlanan karışımlar tungsten karbürden imal edilen ögütme kaplarına yerleştirilmiş ve bilye malzemesi olarak yine tungsten karbürden üretilen $10 \mathrm{~mm}$ çapında bilyeler tercih edilmiştir. Ögüutme kapları iki istasyonlu bir bilyeli ögütücüye (Retsch PM 200) yerleștirilerek, hazırlanan toz karıșımlarının 300 $\mathrm{d} / \mathrm{dk}$ hızda ve 10:1 bilye-toz-ağıllık oranında ögütme işlemleri gerçekleştirilmiştir. Belirli aralıklarla öğütücü durdurularak öğütme kabı sicaklığının ortam sicaklığına düşmesi sağlanmıştır. Her çevrim aralığı sonunda parçacık boyut analizi cihazı (Malvern Mastersizer 2000) kullanılarak ortalama toz boyutları belirlenmiş ve ögütme işlemine tekrar devam edilerek 25 saatlik 
öğütme süresine erişilmiştir. Ayrıca, ortalama toz boyutunun öğütme süresi ile değişimi süresince toz morfolojisindeki değişimler taramalı elektron mikroskobu ile incelenmiştir. Buna göre işlem kontrol katkıs1 olarak etanol ve metanolün kullanılması sonucunda son toz boyutlarında ve morfolojilerinde oluşan farklılıklar ve homojenlik durumları karşılaştırılmış ve Cu25W kompozit tozunun üretimi için \%2'lik ağırlık oranında en uygun sıv1 işlem kontrol katkısının türü belirlenmiştir. $\mathrm{Bu}$ çalışmada, mekanik alaşımlamada görülen $\mathrm{Cu}-\mathrm{W}$ arasında yapısal dönüşüm oluşturmadan ziyade bilyeli ögütme yöntemiyle toz boyut küçülmeleri ile birlikte daha homojen bir içyap1 oluşturma üzerine odaklanılmıştır. Böylece yerel bileşim farklılıkları en aza indirgenerek elementlerin elektrik kontak malzemesi yüzeyleri üzerinde dengeli dağılımı sağlanarak fiziksel ve mekanik özelliklerin iyileştirilmesi amaçlanmıştır.

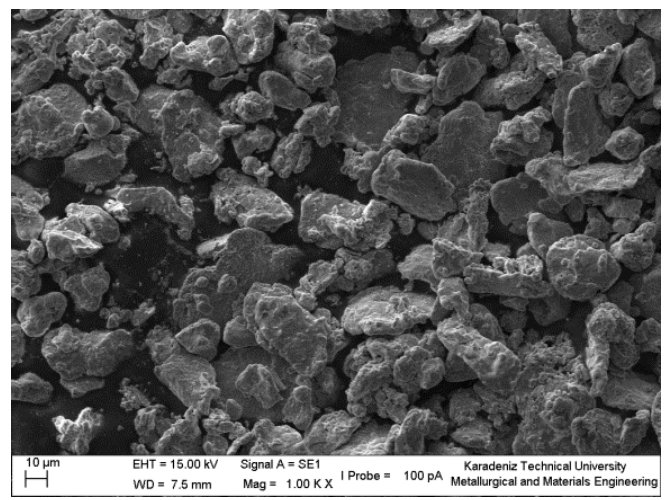

(a)

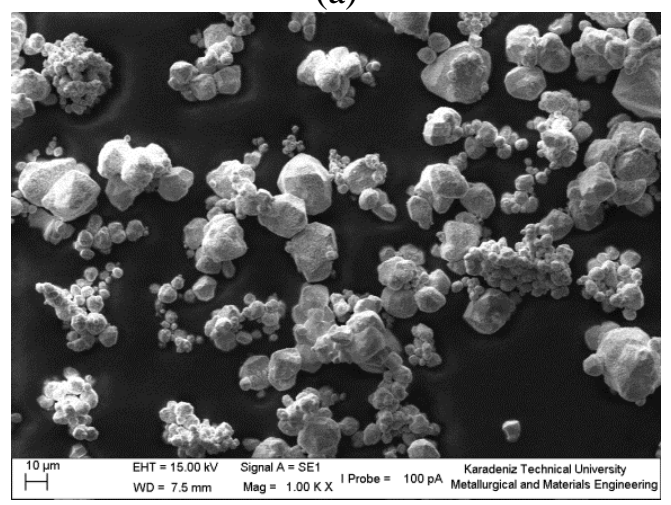

(b)

Şekil 1. Başlangıç toz morfolojileri; (a) $\mathrm{Cu}$ ve (b) W tozu.

\section{Bulgular ve Tartışma}

Başlangıç tozlarına ait taramalı elektron mikroskobu görüntüleri incelendiğinde, $\mathrm{Cu}$ tozunun düzensiz (Şekil 1a), W tozunun ise açılı (Şekil 1b) bir morfolojiye sahip olduğu görülmektedir. Ayrıca, takviye elemanı olan tungstenin matris elemanı olan bakıra göre çok daha düşük boyutlu olduğu aynı görüntülerden desteklenmektedir. Parçacık boyut analizi cihazı kullanılarak her öğütme çevrimi sonunda $\mathrm{Cu} 25 \mathrm{~W}$ toz karışımlarından elde edilen ortalama toz boyutu değerleri Tablo 1'de verilmiştir. Buna göre etanol ve metanol kullanımına bağlı olarak ortalama toz boyutu değerleri de her çevrim aralığı sonunda değişim göstermiştir. İşlem kontrol katk1lı numunelerde gözlenen durumun aksine işlem kontrol katkısı içermeyen numunede artan öğütme süresi ile toz boyutlarında ilk 4 saate kadar artış gözlenmiştir (Bıyık ve Aydın, 2017/2). $\mathrm{Bu}$ bağlamda kısa süreli öğütmelerde işlem kontrol katkısı kullanımının toz boyutu üzerine olumlu etkisi ön plana çıkmaktadır.

Bilyeli ögütme işleminde yüksek enerjili öğütme işlemine maruz kalan toz parçacıkları bilye-tozbilye, bilye-toz-değirmen yüzeyi çarpışmaları sonucunda hem morfolojik hem de boyutsal anlamda değişim gösterirler. Bilyeli öğütme sayesinde sürekli olarak plastik deformasyon, kırılma, soğuk kaynak, yeniden kırılma ve kaynaklanma olayları etkisi ile kademeli olarak değişim gösteren ve son derece homojen mikro yapıların elde edilebilmesi mümkündür. Bilyeli ögütme ile ilgili yapılan çalışmalar gözden geçirildiğinde ögütmenin ilk evrelerinde toz boyutunun soğuk kaynak etkisi altında genellikle dalgalandığı, ilerleyen evrelerde ise kademeli olarak azaldığı ve kararlı hale ulaşttğı görüşü hakimdir (Biylk ve Aydin, 2017). Bununla birlikte, kullanılan tozların başlangıç boyutu ve morfolojisi, öğütücü kap malzemesi, kullanılan bilye malzemesi ve boyutları, bilyeli ögütme değişkenlerinin seçimi, özellikle de işlem kontrol katkısının etkisi; işlem verimi açısından diğer dikkate alınacak etmenler arasında sayılabilir. $\mathrm{Bu}$ çalışmada işlem kontrol katkısı olarak etanol ve metanolün kullanılmas1 sonucunda $\mathrm{Cu} 25 \mathrm{~W}$ toz karışımında ortaya çıkan değişimler Şekil 2'de karşılaştırmalı olarak gösterilmiştir. Şekil 2, Tablo 1'deki değerlerin kullanılması ile elde edilen bir grafik olup, ortalama toz boyut değerlerinin işlem kontrol katkısından bağımsız olarak öğütme süresi ile birlikte kademeli olarak azaldığını ortaya koymaktadır. Söz konusu azalmanın derecesi özellikle ilk 10 saat için daha belirgindir. Sonrasında ise ortalama toz boyutu değerlerinde önemli ölçüde değişim gözlenmemiştir. Başlangıç ortalama toz boyutu $28.897 \mu \mathrm{m}$ olan $\mathrm{Cu} 25 \mathrm{~W}$ tozunun 25 saatlik ögütme süresi sonunda son toz boyutu etanol ve metanol kullanılmasiyla sirasiyla 7.621 ve $4.875 \mu \mathrm{m}$ değerlerine düşmüştür (Tablo 1). İşlem kontrol katkıları ve ortalama toz boyut değerleri incelendiğinde, metanolün etanole göre ortalama toz boyutu değerleri üzerinde daha etkili olduğu görülmüştür (Şekil 2). 
Tablo 1. Artan öğütme süresi ile birlikte etanol ve metanol katkılarına bağlı olarak değişen Cu25W ortalama toz boyut değerleri.

\begin{tabular}{|l|l|l|l|l|l|l|l|}
\hline \multirow{2}{*}{ Kimyasal bileşim } & \multicolumn{6}{|l|}{ Öğ̈̈tme süresi (saat) ve ortalama toz boyutu $(\mu \mathrm{m})$} \\
\cline { 2 - 9 } & 0 & 0.5 & 2 & 4 & 10 & 16 & 25 \\
\hline Cu25W (katk1sız) & 28.897 & 27.771 & 32.751 & 32.760 & 17.225 & 9.366 & 6.964 \\
\hline Cu25W-\% 2 etanol & 28.897 & 24.389 & 20.536 & 17.532 & 10.236 & 8.627 & 7.621 \\
\hline Cu25W-\% 2 metanol & 28.897 & 22.589 & 17.166 & 11.940 & 5.264 & 5.024 & 4.875 \\
\hline
\end{tabular}

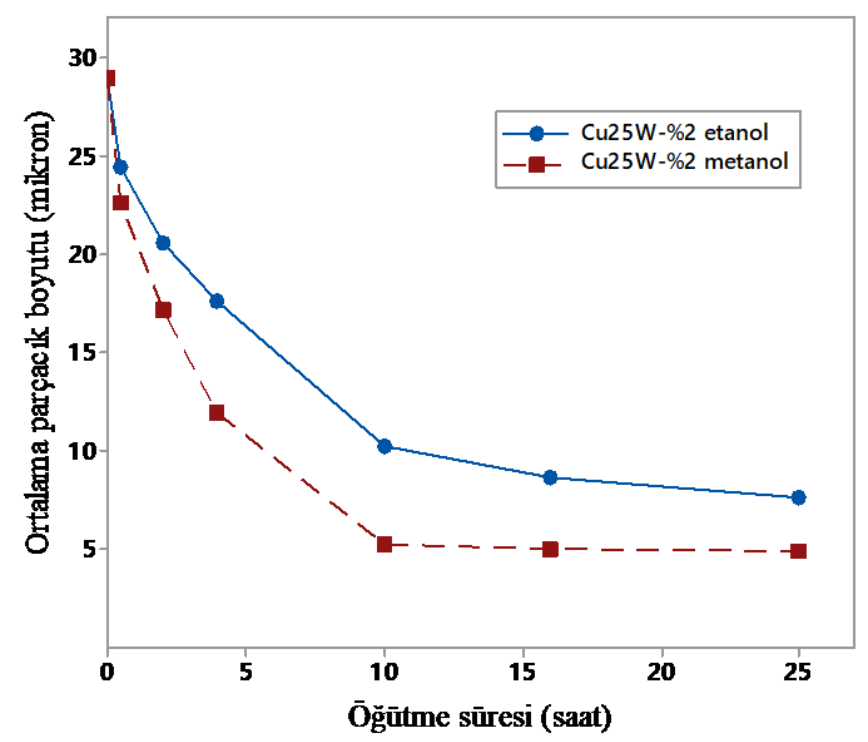

Şekil 2. Etanol ve metanol katkılarının Cu25W toz karışımının ortalama toz boyutuna etkisi.

Etanol ve metanol katkılarının 2, 10, 16 ve 25 saatlik ögütme süreleri sonunda $\mathrm{Cu} 25 \mathrm{~W}$ toz morfolojisine etkisini gösteren SEM görüntüleri Şekil 3’te verilmiştir. İlk 2 saatlik ögütme süresi sonundaki toz morfolojileri incelendiğinde etanol katk111 numunede (Şekil 3a) metanol katk11 numuneye (Şekil 3b) göre daha yüksek oranda pulsu yapıların mevcut olduğu görülmektedir. $\mathrm{Bu}$ durum parçacık boyut analizi sonuçlarına da yansımış ve 2 saatlik ögütme süresi sonunda etanol ve metanol kullanilmasi sonucunda toz boyut değerleri başlangıç boyutu olan $28.897 \mu \mathrm{m}$ değerinden sirasiyla 20.536 ve $17.166 \mu \mathrm{m}$ değerlerine düşmüştür. Aradaki boyut fark1 özellikle soğuk kaynak etkisinin kırılmaya göre baskın olmasıyla belirginleşen pulsu yapıların çoğunlukta olmasından kaynaklanmaktadır. $\mathrm{Bu}$ durum çoğunlukla sünek metal tozlarının öğütülmesi sırasında meydana gelen soğuk kaynak eğiliminin, toz parçacıklarının kırılmasını engelleyici bir düzen oluşturmasıyla ilişkilidir (Suryanarayana, 2004). Toz parçacıkları arasındaki soğuk kaynak etkisini en aza indirmek veya ortadan kaldırmak için özel kimyasallar, yağlayıcılar veya yüzey işlemcileri olarak da bilinen işlem kontrol katkılarının kullanımı büyük önem taşımaktadır. Özellikle ilk 2 saatlik öğütme işlemi sonunda elde edilen toz morfolojileri incelendiğinde takviye parçacıklarının matris tozlar1 üzerinde yeterince homojen dağılmadığ 1 görülmektedir. Artan öğütme süresi ile birlikte, özellikle de 10 saate kadar kırılma etkisinin bilyeli öğütmede soğuk kaynak etkisine göre daha hakim olduğu gözlenmiştir. Söz konusu süre sonunda Tablo 1'den de görüleceği üzere toz boyut değerlerinin etanol katkılı numune için 10.236 $\mu \mathrm{m}$; metanol katk1lı numune içinse $5.264 \mu \mathrm{m}$ değerlerinde olduğu belirlenmiştir. Şekil 3c'de pulsu yapılardaki azalma dikkat çekerken, Şekil $3 d$ 'de ise daha etkin bir kırılma sonucu dengeli bir ögütme işleminin gerçekleştiği görülmektedir. 10 saatlik öğütme süresinin üzerinde etanol katkılı numunede kademeli bir değişim gözlenirken (Şekil 3e ve g), metanol katkılı numunede ise önemli bir değişime rastlanmamıştır (Şekil 3f ve h).

25 saatlik öğütme süresi sonunda toz boyut değerlerinin etanol ve metanol kullanımı için sirasiyla 7.621 ve $4.875 \mu \mathrm{m}$ değerlerinde olduğu tespit edilmiştir. Özellikle $16-25$ saatlik ögütme süresi aralığında toz boyutlarında kayda değer bir boyut küçülmesi gözlenmediği de dikkate alınarak 25 saatlik ögütme süresinin takviye-matris etkileşimi açısından yeterli olduğu görülmüştür. 
Etanol

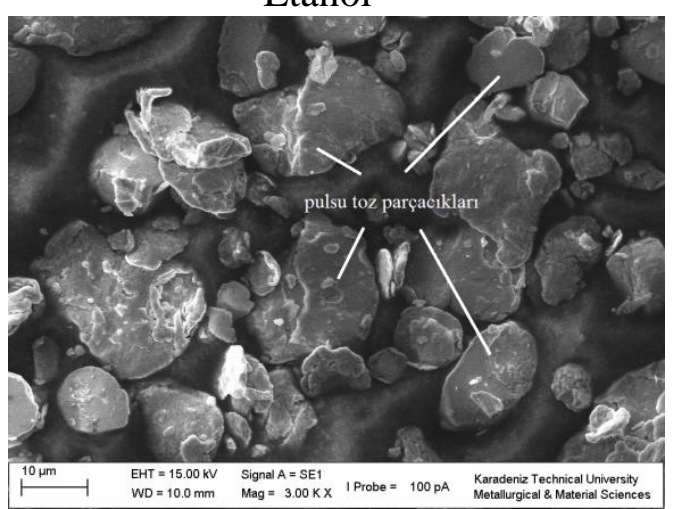

(a)

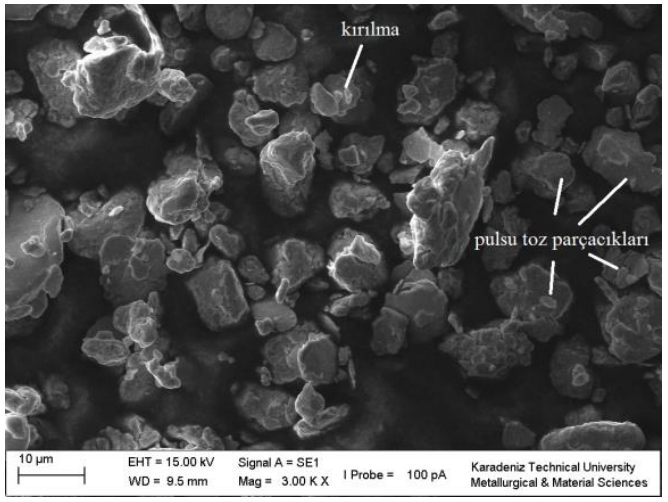

(c)

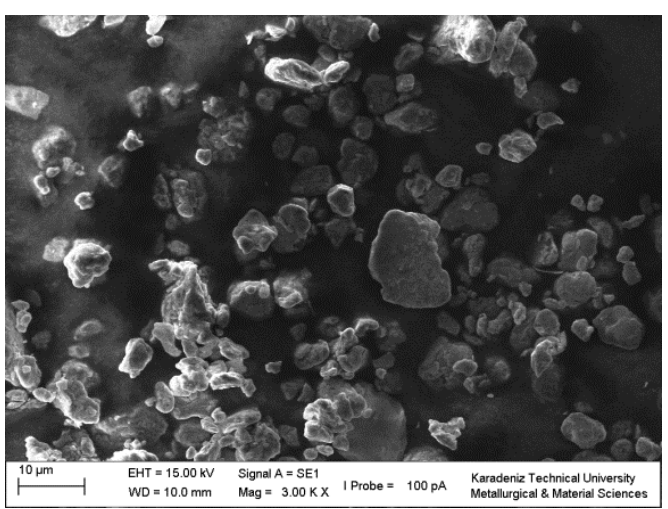

(e)

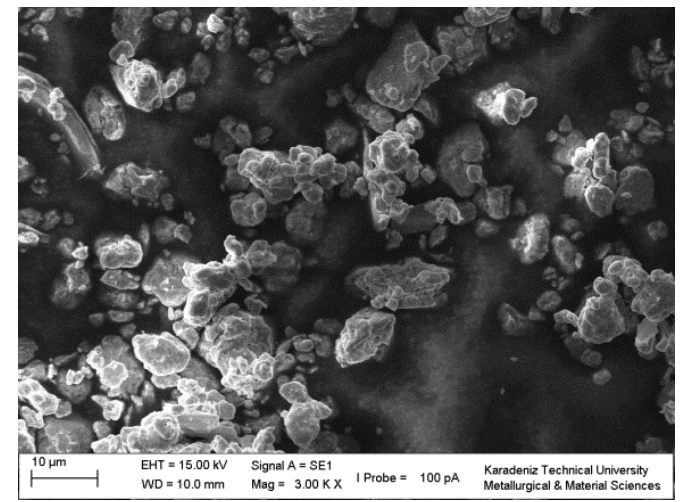

(g)
Metanol

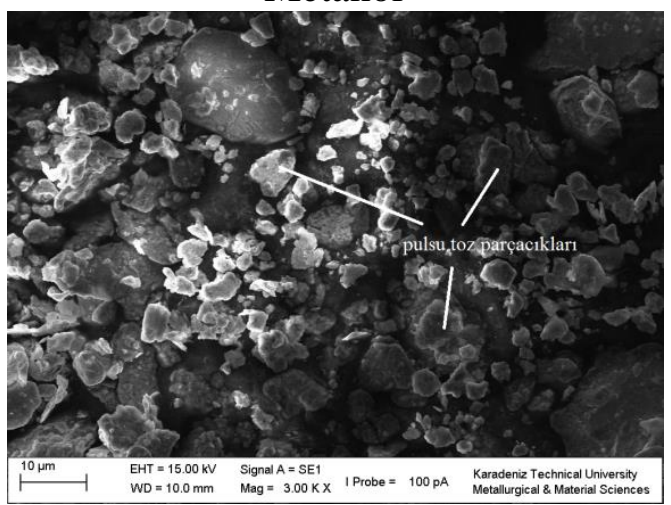

(b)

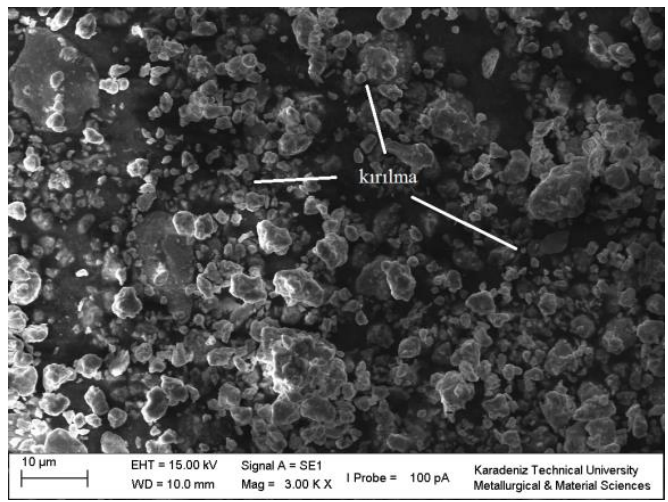

(d)

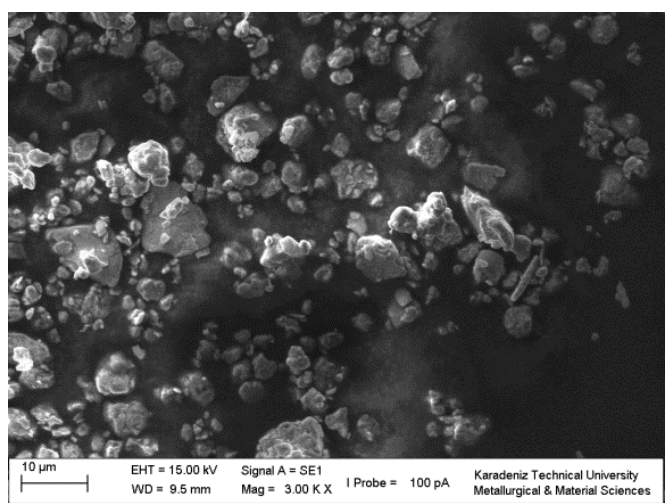

(f)

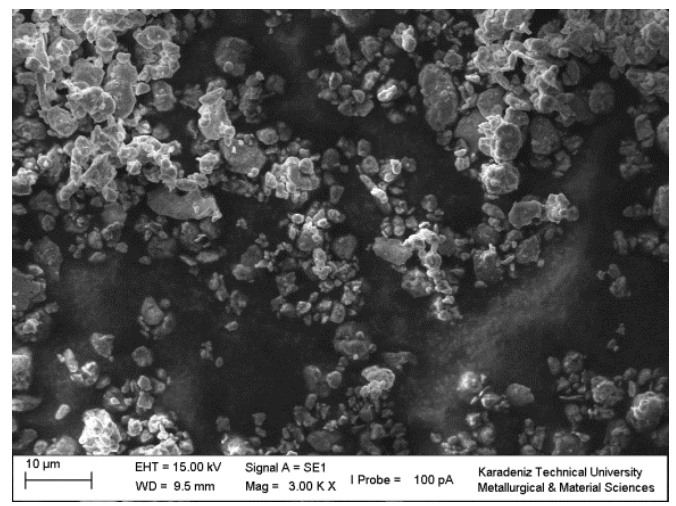

(h)

Şekil 3. Etanol ve metanol katkılarının Cu25W toz morfolojisine etkisi; (a-b): 2, (c-d): 10, (e-f): 16 ve (g-h): 25 saatlik öğütme süresi. 
Öğütme işlemine tabi tutulan tozlarda özellikle ilk 2 saatlik ögütme süresi sonunda plastik deformasyonu gösteren pulsu morfolojinin; 10 saatlik öğütme süresi sonunda kırılma sonucu oluşan düzensiz morfolojinin; 25 saatlik ögütme süresi sonunda ise kırılma ve soğuk kaynak olayları arasındaki dengenin sağlanması ile birlikte sistemin kararlı hale geldiğini gösteren eş eksenli morfolojinin hakim olduğu gözlemlenmiştir. Toz boyut değerlerinin ve Şekil $3 \mathrm{~g}$ ve h'deki SEM görüntülerinin birlikte değerlendirilmesi sayesinde metanol kullanımının $\mathrm{Cu} 25 \mathrm{~W}$ toz boyutu ve morfolojisi üzerinde etanole göre daha olumlu bir etkiye sahip olduğu sonucuna varılmıştır.

Öğ̈̈tme süresi ile birlikte artan ortam sıcaklığına bağlı olarak, işlem kontrol katkıları ergime veya buharlaşmaya maruz kalabilmektedir. Ayrica kimyasal bileşime göre değişim gösteren hidrojen, karbon ve oksijen elementlerinin toza karışarak dağ 11 ım sertleştirmesine katkıda bulunduğu; bazı durumlarda ise hidrojenin tozu gevrekleştirdiği ve böylelikle de daha düşük boyutlu toz üretimine yardımcı olduğu belirtilmiştir (Suryanarayana, 2004). Bu bilgilerin ışığında etanol ve metanol kullanımına bağlı olarak son toz boyutlarında gözlemlenen değişim, iki işlem kontrol katkısının kimyasal ve 1sıl kararlılıkları arasındaki farka dayandırılmaktadır.

\section{Sonuçlar}

Bu çalışmada, bilyeli öğütme yöntemi kullanılarak $\mathrm{Cu} 25 \mathrm{~W}$ kompozit tozunun sentezlenmesi üzerine etanol ve metanol gibi iki farklı işlem kontrol katkısının kullanımının etkisi incelenmiştir. Ögütme süresinin artmasıyla birlikte her iki toz karışımında da ortalama toz boyutu değerlerinde kademeli bir azalma ortaya çıkmıştır. Özellikle metanol katkılı toz karışımlarında ortalama toz boyutu değerlerinde etanol katkılı numunelere göre daha etkili bir kırılma gözlenmesi sonucunda daha düşük toz boyut değerleri elde edilmiştir. Sonuç olarak $\mathrm{Cu} 25 \mathrm{~W}$ kompozitinin sentezinde \% 2'lik ağırlık oranı için, metanol kullanımının etanol kullanımına göre daha avantajlı olduğu belirlenmiştir.

\section{Kaynaklar}

Biyık, S., 2017. Characterization of Nanocrystalline Cu25Mo Electrical Contact Material Synthesized via Ball Milling. Acta Physica Polonica A, 132, (3), 886-888.

Bıyık, S. ve Aydın, M., 2017/1. Fabrication and ArcErosion Behavior of $\mathrm{Ag}_{8} \mathrm{SnO}_{2}$ Electrical
Contact Materials under Inductive Loads. Acta Physica Polonica A, 131, (3), 339-342.

Biyık, S. ve Aydın, M., 2017/2. Optimization of Mechanical Alloying Parameters of $\mathrm{Cu} 25 \mathrm{~W}$ Electrical Contact Material. Acta Physica Polonica A, 132, (3), 909-912.

Biyık, S. ve Aydin, M., 2016. Investigation of the Effect of Different Current Loads on the ArcErosion Performance of Electrical Contacts. Acta Physica Polonica A, 129, (4), 656-660.

Bıyık, S., Arslan, F. ve Aydın, M., 2015. Arc-Erosion Behavior of Boric Oxide-Reinforced SilverBased Electrical Contact Materials Produced by Mechanical Alloying. Journal of Electronic Materials, 44, (1), 457-466.

Bıyık, S. ve Aydın, M., 2015. The Effect of Milling Speed on Particle Size and Morphology of Cu25W Composite Powder. Acta Physica Polonica A, 127, (4), 1255-1260.

Cosovic, V., Talijan, N., Zivkovic, D., Minic, D. ve Zivkovic, Z., 2012. Comparison of Properties of Silver-Metal Oxide Electrical Contact Materials. Journal of Mining and Metallurgy, 48, (1), 131141.

Dong, L.L., Chen, W.G., Deng, N., Song, J.L. ve Wang, J.J., 2017. Investigation on Arc Erosion Behaviors and Mechanism of W70Cu30 Electrical Contact Materials Adding Graphene. Journal of Alloys and Compounds, 696, 923930 .

Feng, Y., Yuan, H.L. ve Zhang, M., 2005. Fabrication and Properties of Silver-Matrix Composites Reinforced by Carbon Nanotubes. Materials Characterization, 55, 211-218.

Li, H.Y., Wang, X.H., Liu, Y.F. ve Guo, X.H., 2017. Effect of Strengthening Phase on Material Transfer Behavior of Ag-based Contact Materials under Different Voltages. Vacuum, 135, 55-65.

Pandey, A., Verma, P. ve Pandey, O.P., 2008. Comparison of Properties of Silver-Tin Oxide Electrical Contact Materials Through Different Processing Routes. Indian Journal of Engineering \& Materials Sciences, 15, 236-240.

Shi, Q., Yang, J., Peng, W.X., Dong, J.Z., Chu, Y.Q., Tang, H. ve Li, C.S., 2015. Synergetic Effect of $\mathrm{NbSe}_{2}$ and $\mathrm{Cr}_{2} \mathrm{Nb}$ on the Tribological and Electrical Behavior of $\mathrm{Cu}$-based Electrical Contact Composites. Rsc Advances, 5, (122), 100472-100481.

Suryanarayana, C., 2004. Mechanical Alloying and Milling. CRC Press, Boca Raton, FL, 488p. 
Yusefi, A. ve Parvin, N., 2017. Fabrication of Three Layered W-Cu Functionally Graded Composite via Spark Plasma Sintering. Fusion Engineering and Design, 114, 196-202.
Zhu, S., Liu, Y., Tian, B., Zhang, Y. ve Song, K., 2017. Arc Erosion Behavior and Mechanism of $\mathrm{Cu} / \mathrm{Cr} 20$ Electrical Contact Material. Vacuum, 143, 129-137. 